\title{
EXPORT OF SMES AFTER THE CRISIS IN THREE EUROPEAN PERIPHERAL REGIONS - A LITERATURE REVIEW ${ }^{1}$
}

\author{
ANDREA ÉLTETŐ \\ Senior Research Fellow, Centre for Economics and Regional Studies of the Hungarian Academy \\ of Sciences, Institute of World Economics \\ Email: elteto.andrea@krtk.mta.hu
}

After the serious effects of the international crisis of 2008 export activity - as a main form of internationalisation - proved to be an important element of survival and growth for small and medium sized enterprises. Recovery was especially difficult for the so-called peripheral countries, among them the Iberian, Baltic and Visegrád economies, on which this article concentrates. The observed period is between 2008 and 2016. First, a brief theoretical overview is given on SME internationalisation. Second, a literature review focuses on the export enhancing factors based on existing enterprise surveys and studies prepared after the crisis. These show that peripheral area SMEs are already similar to others regarding these stimuli, manager attitude and innovation being the most important ones. Third, statistical data are analysed to assess the significance of SMEs in employment, value added and exports. In this respect, SMEs and their pace of recovery are somewhat different in the three regions but not so distinct from the core countries. Finally, it is shown that in the post-crisis period, two main changes can be perceived: the temporary shift of exports towards non-EU markets and structural rearrangements in exporting enterprises.

Keywords: SMEs, export, internationalization

JEL-Code: F10

The article is based on the research supported by the National Research Development and Innovation Office, project no. K 115578, title: "Factors influencing export performance - a comparison of three European regions" 


\section{INTRODUCTION}

European small and medium-sized enterprises (SMEs) ${ }^{2}$ suffered from the effects of the 2008 international crisis. Decreasing demand, worsening access to credit, finance, delayed payments and postponed orders caused serious difficulties for these firms (OECD 2009). The number of SMEs in 2009 fell (Ecorys 2011), with the pace and extent of recovery afterwards different along European regions. Export activity was an important component of this recovery, since it provided revenues to the firms and countries. This had been more pronounced in periphery areas of the EU where GDP decreased significantly. The aim of this article is to compare the export behaviour of SMEs in the Iberian, Baltic and Visegrád countries that geographically belong to the peripheries or semi-peripheries of the EU. ${ }^{3}$ The examined period is 2008-2016, which includes the post-crisis and recovery years. The methodology is the comparative analysis of the existing literature, as well as the analysis of statistical data.

Foreign trade was the most popular form of internationalization among European SMEs even before the crisis. More than 26-30\% of European SMEs were involved in exporting or importing between 2006-2009, while less than $8 \%$ were active in other modes of internationalization (EIM 2010). SMEs' foreign trade activities have increased after the crisis as their domestic markets shrunk. Wach (2014) points out that a comparative analysis about the internationalization of SMEs is difficult, because data is often collected at different time intervals with different methodologies. However, certain general indicators can be gathered; the Eurostat Comext Trade Enterprise database provides data on SMEs' export activities. The SME Performance Review regularly published by the European Commission monitors the development of SMEs in each EU country. The Small Business Act (SBA) Fact Sheets are published each year and provide a general view of the distribution and role of firms according to their size in the economy.

The structure of the article is the following: first a brief theoretical background on SME internationalization is provided, followed by a literature review on the factors that helped SME exports in the three regions analysed. Surveys prepared after the crisis are the basis of this review. Finally, the structure and significance of the small and medium-sized enterprises in the regions are shown via Eurostat data. Similarly, the characteristics of SME export activity are described illustrating their role in the economies.

2 According to the EU's definition, SMEs have less than 250 employees, a turnover of less than or equal to 50 million euros and a balance sum of less than or equal 43 million euros.

The countries are the following: Portugal, Spain, Hungary, Slovakia, Czech Republic, Poland, Lithuania, Latvia and Estonia 


\section{BRIEF OVERVIEW OF THE THEORETICAL BACKGROUND OF SME INTERNATIONALIZATION}

Over the last decades, research on SME internationalization has grown vastly. Several studies explained how SMEs internationalize (Lu - Beamish 2001; Hutchinson et al. 2005; Doole et al. 2006; Ruzzier et al. 2006). Ribau et al. (2018) summarize research on SME internationalization between 1977 and 2014 evaluating 554 studies published in international journals. They observe the dominance of Europe in the research and the growing importance of the topic reflected in a rising number of articles since 2006.

SMEs are not smaller large enterprises, they also have some distinguishing features: less capital, lower access to information, but more dynamism and flexibility. Kubícková et al. (2014) points out that these enterprises are frequently managed by only one or a few managers (often family members) with limited financial resources and low mobility. Although the literature on the effects of family ownership on SMEs' internationalization is growing, results are mixed (Merino et al. 2015, Carlos Lopes et al. 2014). Small firms also differ from large ones in their organizational structure and a low degree of division of labour. Further, SMEs can focus more on specific strategies than large firms can.

According to the broad definition, internationalization is "the process of increasing involvement in international operations" (Welch - Luostarinen 1988: 36). We can group traditional theories on internationalization into stage, network and international entrepreneurship approaches (Lin 2010). A large number of studies discuss these approaches (e.g. Laghzaoui 2011), here, we focus on their relevance regarding export activity.

The most cited basic stage model is the Uppsala model (Johanson et al. 1975; Johanson - Vahlne 1977), describing internationalization as a process of gradual learning through experiences gained in foreign markets. ${ }^{4}$ The stages of internationalization are geographic: first, targets are neighbouring countries, then, more distant, but culturally similar countries and finally physically and culturally far-away economies. Experimental knowledge is acquired through personal experience, which is focal in reducing "psychic distance" - the sum of language, cultural and political differences (Zhang 2014; Ojala 2015). The Uppsala model was criticized following its inception, on the grounds that its relevance for SMEs

4 Thus, internationalization is a process of four sequential steps where each consecutive step means an increased resource commitment: 1 . irregular export activities; 2 . export through independent agents; 3 . establishment of an overseas sales subsidiary; 4. establishment of manufacturing subsidiaries abroad. 
is limited. ${ }^{5}$ A number of researchers (e.g. Cavusgil 1980; Reid 1981) support the Innovation-Related Model, which considers the internationalization process an innovation for enterprises. Its basis is the export share in the enterprise's turnover that leads to a stepwise perspective on internationalization. Exportengagement is gradual in this model as well, with three main stages identified (Leonidou - Katsikeas 1996). ${ }^{6}$ The Innovation-Related Model highlights the importance of factors like managerial knowledge, motivation and behaviour, but its sequential feature has been criticised. Gankema et al. (2000) and Laghzaoui (2011), amongst others, showed that SMEs can jump steps, while others may stop shortof the final step(s). The sequential process is also questioned by the literature on the grounds of non-linear internationalization, meaning that firms can exit foreign market(s) or reduce exports, but re-enter these markets later. Re-internationalization can take place several times and often in the case of smaller firms (Welch - Welch 2009; Vissak 2010; Javalgi et al. 2011). Observing activities and behaviour of SMEs led to the introduction of new internationalization approaches.

The network approach emphasizes that firm networks are fundamental for SMEs to be able to develop their limited resources (Johanson - Vahlne 1990). In addition, other studies (Johanson - Mattson 1988; Coviello - Munro 1997) pointed out that the establishment of financial, technological and commercial relations with other partners of the network enables the firms to extend their activities internationally. In the past two decades, the growing importance of global production chains made network internationalization of SMEs especially relevant.

The entrepreneurship approach denies the sequential stages of internationalization, showing the existence of born global firms or international new ventures (Rennie 1993; Oviatt - McDougall 1994; Cavusgil 1980). These can export or invest abroad right from the start, leading to the SMEs' rapid international development. A common feature of born global firms is that the management adopts a global vision when founding the enterprise and embarks on rapid internationalization. These firms are usually knowledge and high-tech intensive, and their study is important for export promotion policy and for management studies (Rasmussen - Madsen 2002). Companies coined "born-again globals" can decide to internationalize rapidly after a long period of domestic focus (Bell et al. 2001). These firms are traditional, domestically well-established SMEs, with

5 The Uppsala model was based on four case studies of Swedish large multinational companies: Volvo, Sandvik, Atlas Copco, Facit.

6 These are: 1. pre-export: the enterprise is active only in domestic market and prepares to export; 2. export trail: the enterprise starts to export irregularly; 3 . advanced export: the enterprise exports regularly and conceives other forms of commitments to international markets. 
no (or limited) motivation to internationalize, but a critical event (e.g. changes in ownership or management) or strategic management decision prompts them to develop their activities in foreign markets (Kalinic Forza 2012). In the past two decades, a growing number of traditional SMEs have accelerated their international activities this way.

The literature distinguishes between push and pull factors amongst motivation for internationalization (export) (Etemad 2004; Danik et al. 2016). Push factors include worsening domestic economic conditions, regulatory constraints, limited or no growth opportunities, excess capacity and proactive managerial attitude. Pull factors can be the opportunities offered by the foreign market, development of info-communication, technology, etc.

Analysis of SME internationalization gave impetus to the rise of several "nontraditional" research approaches. Rod et al. (2016) collected concepts that can be especially descriptive of SMEs. One is the effectuation theory, using available resources, affordable loss, adaptation to changes, building partnerships and controlling the existing internationalization process (Sarasvathy 2001). Another concept is the theory of bricolage that focuses on resource constraints faced by entrepreneurs, who improvise to achieve success by reconfiguring their existing means. Additionally, resource scavenging is a relatively new approach concerned with obtaining internationalization as a process to attain resources. Social capital is defined as the sum of resources that can potentially be derived or obtained from a social network. Apart from these, Rod et al. (2016) mention the concept of muddling through (moving away from the present situation, not particularly toward something) and the Dynamic Experimental Internationalization theory as non-traditional approaches. The latter notes that SMEs in transitional economies face rapidly changing environments, limited experience, and limited information so they adopt an experimental, intuitive, and spontaneous process, which allows them to take advantage of emerging opportunities.

Because of the economic crisis-spurred push factor of reduced domestic demand, SMEs began or consolidated exports in the three European regions examined. This was especially the case for numerous Iberian companies (see eg. Oliveira - Teixera 2011; Sánchez, et.al. 2014), where increasing exports proved to be the only way to survive. We can also find examples of nonlinear internationalization behaviour among European SMEs, like stopping exports (completely or towards certain markets) during the crisis and restarting these later (Vissak Francioni 2013; Dominguez - Mayrhofer 2017). The theory of international new ventures is underpinned by several examples from the Baltic countries (Mets 2016; Sekliuckiene 2014, 2017) and the network approach of internationalization is highly relevant for the Visegrád countries that are embedded in global production networks (Jankowska - Glówka 2016; Musteen et al. 2014). In the 
following, a literature review is provided of the patterns of SME internationalization in the Visegrád and Baltic areas (Central and Eastern Europe) and in the Iberian region.

\section{LITERATURE REVIEW ON SMES' INTERNATIONALIZATION IN THE THREE REGIONS}

SMEs in certain geographical regions can have specificities based on historical, cultural and economic and political specificities. The patterns of SME-internationalization in the CEE region have been discussed in the literature and several studies have examined the features of internationalization of Portuguese and Spanish companies too, especially after their accession to the EU. All three regions have had a authoritarian past and the transition to democracy was politically and economically anchored to the EU.

There are company surveys in the three regions that analyse the factors that drive exports in the post-crisis period. Governments generally intend to promote the exports of SMEs and favourable business environment can be an important external factor to ease export (for more details, see Antalóczy - Éltető 2016). However, there are also internal factors to increase a firm's competitiveness. One group of internal factors concerns the product characteristics of the firm (its quality, development, adaptation, and production cost reduction). Another group consists of the features of the workforce (specialised, qualified employees, expertise, managerial behaviour). Foreign market-related factors (finding customers, contacts, network, marketing) form a third group. The surveys mentioned in the following part reveal several factors that are behind the successful exports of these three groups.

\subsection{Iberian SMEs - increased internationalization}

In the Iberian countries, the role of small and micro (often family-owned) companies is traditionally large. During the 1990s, the degree of internationalization amongst Spanish companies had been relatively low, but increased in the next decade. The international crisis of 2008 induced a strong wave of internationalization, the number of exporting Spanish SMEs and export intensity of the firms increased considerably. Many companies "tried their luck" on foreign markets, but few were able to maintain their foreign position or export considerable volumes (García - Canal 2013). Bonet and Minguez (2015) find that firms that began exporting in 2005 on average had one foreign market, which increased to four by 
2014. Garrido et al. (2016) argue that in a period of economic crisis companies can reorganize their geographic diversification strategy easier and quicker than their product diversification strategy. ${ }^{7}$ Their main partners are core EU countries, Portugal, Morocco and some culturally close Latin American areas (Banco de España 2015).

The crisis showed that weak domestic demand elevates the probability of exporting. However, $80 \%$ of SMEs intend to continue international expansion in the coming years, despite increasing domestic demand (CEDI 2015). ${ }^{8}$ Regarding external factors of export success, $73 \%$ of the responding firms consider public support to be non-decisive in their internationalization, although the majority calls for trade promotion and for export financing. As for the key internal stimulating factors, companies mentioned competitive prices first, then adequate human resources, the brand and establishment of strategic alliances. Foreign ownership can also help internationalization; González and Martín (2015) find that SMEs with foreign capital export more and take part in global value chains more intensively than domestic ones. Ortiz et al. (2015) found that the management's international experience and greater technological activities have a positive influence on the exporting commitment of companies, based on the analysis of 343 Spanish SMEs. Merino et al. (2015) found that expertise of a generation and family business culture influences export activity positively. The authors had a sample of $500 \mathrm{Spanish}$ SMEs, where more than half were family-owned. Fernández-Olmos et al. (2016) also study the consequences of "familiness" and argue that the path of internationalization of family firms is not linear but rather shapes a W curve. ${ }^{9}$ Analysing panel data between 2006 and 2011, the authors find that family firms are more reluctant to diversify geographically and firm size matters for export intensity.

Pinilla (2016) proves the positive effects of innovation activity and capacity on internationalization and export of SMEs with an econometric analysis of 272 Catalan SMEs. Fernandez-Serrano-Romero (2013) find differences in internation-

7 Their results of a sample of 100 independent stock-exchange listed companies (giving $34 \%$ of Spanish GDP) reveal that most of the firms have increased geographic diversification in the period between 2006 and 2011, whereas about half of the companies have increased product diversification.

8 The survey of CEDI gathers the opinions of 1,385 executives from exporting companies.

9 In a first stage, family firms expand within their home region, because they lack financial resources, managerial capabilities and external networks to internationalize. In a second stage, family firms consolidate their positions in this market by attaining new knowledge. In the third stage, firms grow by progressively exporting into culturally distant markets, but they experience their lack of resources, capabilities, growing costs of coordination and governance when the degree of internationalisation increases. Finally, they build networks, and accumulate capabilities once the family firms reach a higher degree of internationalisation (Fernández-Olmos et al. 2016: 131). 
alization patterns between low and high-income Spanish regions, when studying 663 SMEs. They report that SMEs in low-income areas introduced less product and process innovations, but were more active in the acquisition of external technology. Apart from that, SMEs in low-income economies are less frequently involved in production co-operation, but they cooperate more in marketing, publicity, distribution and sales.

In Portugal, exports grew dynamically between 2010 and 2014 - the share of exporting SMEs increased in number and in turnover. Their contribution to the total turnover of Portuguese firms increased from 27 to 34 percent in 2007-2016 (Banco de Portugal 2017). Spain and France are the most important markets for Portuguese firms, followed by Germany and after the crisis the role of Angola and Brazil has also increased.

Oliveira and Teixeira (2011) describe the characteristics of Portuguese SMEs' internationalization based on a sample of 912 firms. About $85 \%$ of the firms are internationalized, mostly via exports. The sample showed that the higher the export stage, the higher the resources committed to internationalization, the international business experience, and dependence on external markets and partners. Export-reliant firms have 11 foreign target countries on average, although the majority of exports are aimed at 2-3 of them. Furthermore, the number of partnerships of the respondent firms tends to increase with export intensity.

Deloitte-AICEP (2014) showed that among the 412 Portuguese firms surveyed, "the saturation of the national market" and "improve rentability" proved to be the most important reasons for going international, followed by "explore market niches". In a survey of 124 Northern Portuguese firms, Macedo (2010) found that the main motives at the selection of the first export market were "market potential" and "opportunity for good business". Already existing relations also played a role and the majority of firms chose culturally close markets. Correia and Gouveia (2016) emphasize the role of innovation and investment as exportenhancing factors, based on financial accounting data of Portuguese companies in 2010-2013.

\subsection{SMEs in Central and Eastern Europe}

Existing formal institutions in most CEE countries collapsed with the systemic change in the early-1990s and new formal institutions only gradually emerged. Companies faced a prolonged period of uncertainty on how to operate best, due to a regulatory vacuum and ambiguous social norms (Gelbuda et al. 2008). CEE countries were differentiated from leading economies because of the history of the planned economy, weak institutions and insufficient innovation capacities 
(Caputo et al. 2016). Stoian et al (2016) call attention to the lack of resources and importance of networks in the internationalization of small firms in the CEE region. These countries have been EU members for over a decade and many firms have been successful on international markets, making it relevant to examine whether CEE firms still carry their socialist legacy and characteristics of conducting business in local ways. Caputo et al. (2016) give a systematic literature review on CEE firms' internationalization (they do not distinguish according to firm size). In the following pages, we focus on the Visegrád and Baltic countries and on those studies that delineate SMEs, and were written after the crisis.

Using data from 297 Czech companies, Zapletalová (2015) confirmed that most SMEs follow two basic models of internationalization in the Visegrád region: the stage model and the early internationalization model. Firms prefer exports as an entry mode to foreign (first of all neighbouring) markets. New international ventures have been on the rise in the Czech Republic since 2000, mostly due to governmental support for innovation incubators and start-ups (Reková 2016). Danik et al. (2016) and Kowalik et al. (2016) analysed some internationalization features of Czech international new ventures and SMEs based on surveys (sample of 590 firms). Having a managerial global vision and product innovations proved to positively influence the internationalization process. Czech SMEs typically start their expansion in the neighbouring countries within the CEE region. Zapletalová (2017) found that the level of business knowledge of managers has the greatest influence on decision-making amongst the 246 Czech family SMEs analysed.

Hungarian SMEs mainly internationalize by exporting products, as opposed to equity investment. A survey made in 2015 on 350 medium-sized companies showed that $60 \%$ of them export and for $34 \%$ half or more of revenues stem from exports (Deloitte 2016). According to Szerb et al. (2013), the success of significant Hungarian exporters include: good quality products, excellent contacts, language knowledge, competitive prices, qualified employees and managers, developed technology, adaptation to international standards and having information on foreign market possibilities. Kovács (2014) shows that exports supported by managerial attitude and strategic partnerships have played an important role in internationalization of the five Hungarian globals they analysed.

Kazai and Pecze (2014) prove that successful export-oriented SMEs ${ }^{10}$ thought strategically and were responsive. Successful exporters rationalized their product range, improved production efficiency, developed new products and looked for new markets. Inzelt (2017) surveyed 246 companies online in knowledge intensive service and technology-intensive manufacturing industries. The increased

10 Successful exporters are characterized by high export revenue, export intensity and profitability. 
export activity of innovative compared to non-innovative firms suggests that positive innovation performance may encourage external market presence. Alternatively, an external market presence may encourage and boost innovative activities. More than half of innovative enterprises sell on the EU market, while only one fifth of non-innovative firms do so. Network internationalization is present in the sample but only at $10 \%$ of the companies.

Internationalization of Polish companies remains at a much lower level than in the Western countries, despite the gradual increase in exports after the crisis (Czerniak - Stefanski 2015). Polish SMEs indicated "prospects of long-term cooperation with foreign partners" as the most important motivation to export followed by "high demand in foreign market" and "rentability." According to the survey prepared by Malecka (2017) of 238 firms, the main barrier to internationalization is financial, although SMEs are reluctant to apply for public support.

Jarosiński (2013) provides a literature review on Polish papers on internationalization and finds that both the stages model and the model of early internationalization exist in Poland, while born globals started to appear already in early 1990s - similarly to more developed countries. Danik et al. (2016) found that the major internal drivers behind rapid internationalization were the founder's personality, managerial reactions and their own network of relations. The main external factors of foreign expansion were business opportunities abroad and possibilities to enter a multinational network. Managerial attitude stands out in the article of Kowalik et al. (2016), who analysed a sample of 233 Polish SMEs and confirmed the correlation between managerial global vision and the speed of foreign market entry. Innovation also contributes to the intensification of the internationalization process, as described by Wach (2016) based on a sample of 263 high-tech firms, half of them SMEs. Fonfara (2015) proved that openness to cooperation in a network - accompanied by an active creation of relationships with foreign entities - enables companies to achieve better performance compared with the competition, based on a sample of 272 Polish firms ( $70 \%$ of them were SMEs).

A relatively large share of Slovakian SMEs are subcontractors to another company in the EU (Malega 2017). Concerning the direction of foreign trade, micro and small enterprises are oriented towards the neighbouring Central European countries, while medium and large companies are mostly active in international trade with core EU-countries. Horská and Gálová (2014) show that two thirds of successfully internationalised firms implemented (mainly product) innovation in the last three years. Based on case studies of Slovakian born globals, Kokavcová (2016) finds that a key element of internationalization is the mindset of top

11 Survey of the Polish Agency for Enterprise Development, cited by Malecka (2017). 
management. Firms used differentiation strategies to create a market niche for themselves with high-quality customized products.

Regarding the export characteristics of the Baltic firms, an Estonian SME survey (cited by Eurofound (E) 2013) confirmed that SMEs trade their products over a short distance. ${ }^{12} \mathrm{~A}$ driver of Estonian firms' exports is the limited domestic market. In many sectors, there are a few enterprises monopolising the market, pushing "born globals" to focus on exports. According to the Estonian Ministry of Economic Affairs (2015), the competitive advantage of these is in the quality of their products, good contact network, low production cost, professional expertise of employees. Customers proved to be the most important competitivenessenhancing factors in exports, followed by product development. Mets (2016) concludes that entrepreneurial ecosystems (accessible markets, human capital, funding, support and regulatory systems, education) are effective incentives for the companies to internationalise rapidly, overcoming the spatial and distance limitations traditional SMEs have.

In Latvia, the crisis induced a restructuring among firms. Major barriers to the development of SMEs were access to qualified employees, funding and strong competition. Analyses after the crisis concluded that Latvian companies should increase the level of innovation and take more business risks (Eurofound (L) 2013). Putninšs (2013) found that exporters are larger, more productive, innovative, proactive and risk-taking, therefore have higher entrepreneurial orientation. Very important factors of export success are having an exporting vision, conducting research on export markets and marketing activity.

The survey of Korsakiene (2014) proved that Lithuanian firms aim to internationalize mainly through export activities, because this is the cheapest and quickest way of internationalization. The internationalized firms confirmed the relevance of "psychic" distance; they mainly export to neighbouring countries (Latvia, Estonia and Poland). According to Korsakiene and Tvaronaviciene (2012), Lithuanian SMEs stressed difficulties in accessing financial resources as well as startup costs as barriers to internationalization. Korsakiene (2014) also shows that own products or services are the major strengths for exports and internationalization, followed by the search for new opportunities and information on customers. Skilled labour and personal relationship appear among motivations to internationalise. Sekliuckiene (2017) analysed case studies of born global Lithuanian SMEs and found that entrepreneurial vision, formal and informal contacts are extremely important in rapid internationalization.

12 Finland was the main export target market for SMEs (61\%), followed by Latvia (31\%), Sweden $(26 \%)$, Russia (16\%) and Germany (15\%). 
Table 1. Factors of successful internationalization after the crisis

\begin{tabular}{|c|c|c|}
\hline Countries & Internal factors & External factors \\
\hline Spain & $\begin{array}{l}\text { product price, human resources, brand, strategic } \\
\text { alliances, management's international experi- } \\
\text { ence attitude, innovation }\end{array}$ & domestic market shrinkage \\
\hline Portugal & $\begin{array}{l}\text { international business experience, innovation, } \\
\text { partnerships }\end{array}$ & domestic market saturation \\
\hline Poland & $\begin{array}{l}\text { managerial attitude and reaction, own network } \\
\text { of relations, innovation }\end{array}$ & $\begin{array}{l}\text { high demand abroad, busi- } \\
\text { ness opportunities, network }\end{array}$ \\
\hline Czech Republic & $\begin{array}{l}\text { managerial global vision, knowledge, } \\
\text { innovation }\end{array}$ & - \\
\hline Slovakia & $\begin{array}{l}\text { innovation, mind-set of management, product } \\
\text { development }\end{array}$ & - \\
\hline Hungary & $\begin{array}{l}\text { managerial attitude and strategic partnerships, } \\
\text { product development, innovation }\end{array}$ & new opportunities abroad \\
\hline Estonia & $\begin{array}{l}\text { quality of products, good contacts, low produc- } \\
\text { tion cost, professional expertise of employees, } \\
\text { managers }\end{array}$ & accessible markets \\
\hline Latvia & $\begin{array}{l}\text { innovation, proactive attitude of manager, } \\
\text { marketing }\end{array}$ & - \\
\hline Lithuania & $\begin{array}{l}\text { skilled labour, personal contacts, management } \\
\text { vision }\end{array}$ & opportunities abroad \\
\hline
\end{tabular}

Source: author, based on surveys cited in the main text.

If we compare the major export-promoting factors found in the surveys focusing on the period after the crisis (see Table 1), we can find that two common internal parameters stand out: the role of the management (attitude, expertise, vison) and innovation. In this respect, these countries are not different from other EU or global economies - effects of managerial behaviour on export have already been proven in research articles in the eighties (Leonidou et al. 2010). Similarly, it has been demonstrated that innovation ( $\mathrm{R} \& \mathrm{D}$, technology) is a major factor that facilitates exports and internationalization (Ribau et al. 2018). Much less emphasis was placed on external factors in the surveys, domestic market shrinkage/saturation was mentioned in the Iberian countries and demand/opportunities on foreign markets in the CEE countries. 


\section{ENTERPRISE STRUCTURE AND SME EXPORT IN THE OBSERVED COUNTRIES}

\subsection{Enterprise structure}

The overwhelming number (98-99\%) of companies in all European countries consists of SMEs. However, their weight in value added and employment is much less. Figure 1 and 2 show the evolution of the share of SMEs in employment and value added respectively, between 2010 and 2015 .

SMEs increased their share in value added in the Baltic countries, but in the Czech Republic, Slovakia, Hungary and Spain there was a decrease. SMEs' share decreased also in employment in the Iberian countries, Hungary, the Czech Republic and to a small extent in Estonia.

Table 2 shows the significance of SME types (based on the number of employees) in the observed economies. Although from 2014 the SME sector experienced growth in Spain, value added and employment are still $23 \%$ and $20 \%$, respectively, below their 2008 levels. Similarly, the traces of the crisis can still be found in Portugal; 2016 SME employment and value added were still $15 \%$ and $8 \%$, respectively, below pre-crisis levels (European Commission 2017).

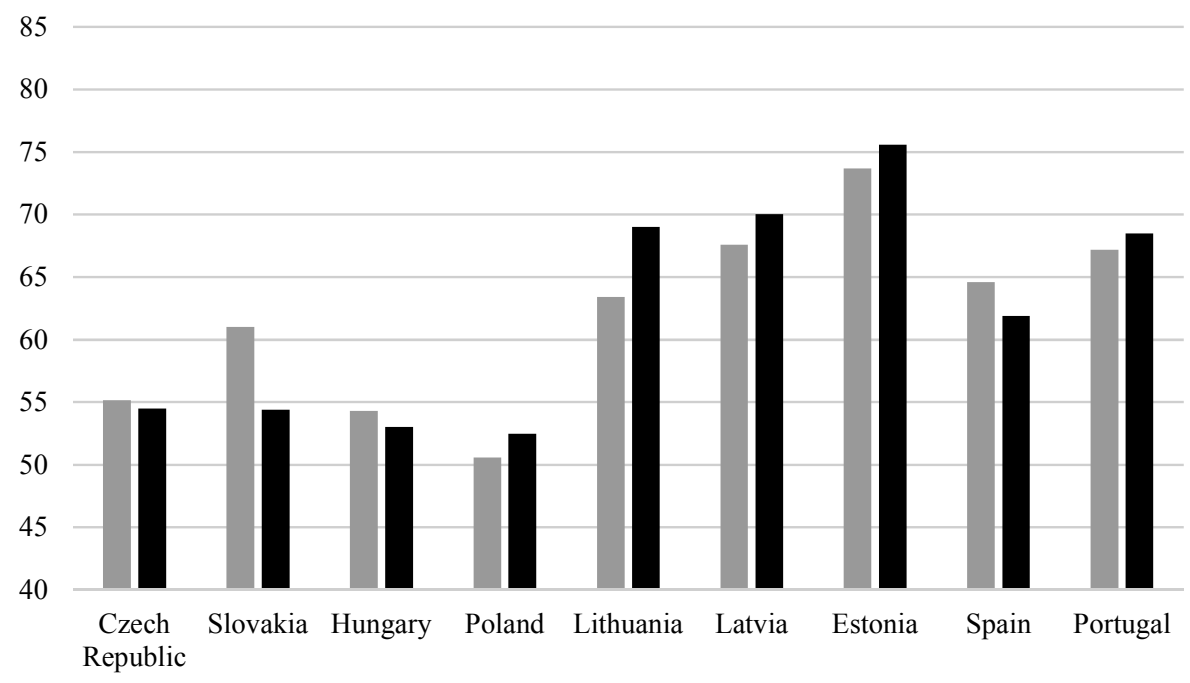

$\square 2010 \square 2015$

Figure 1. Share of SMEs in the total value added of companies

Source: Eurostat Structural Business Statistics 


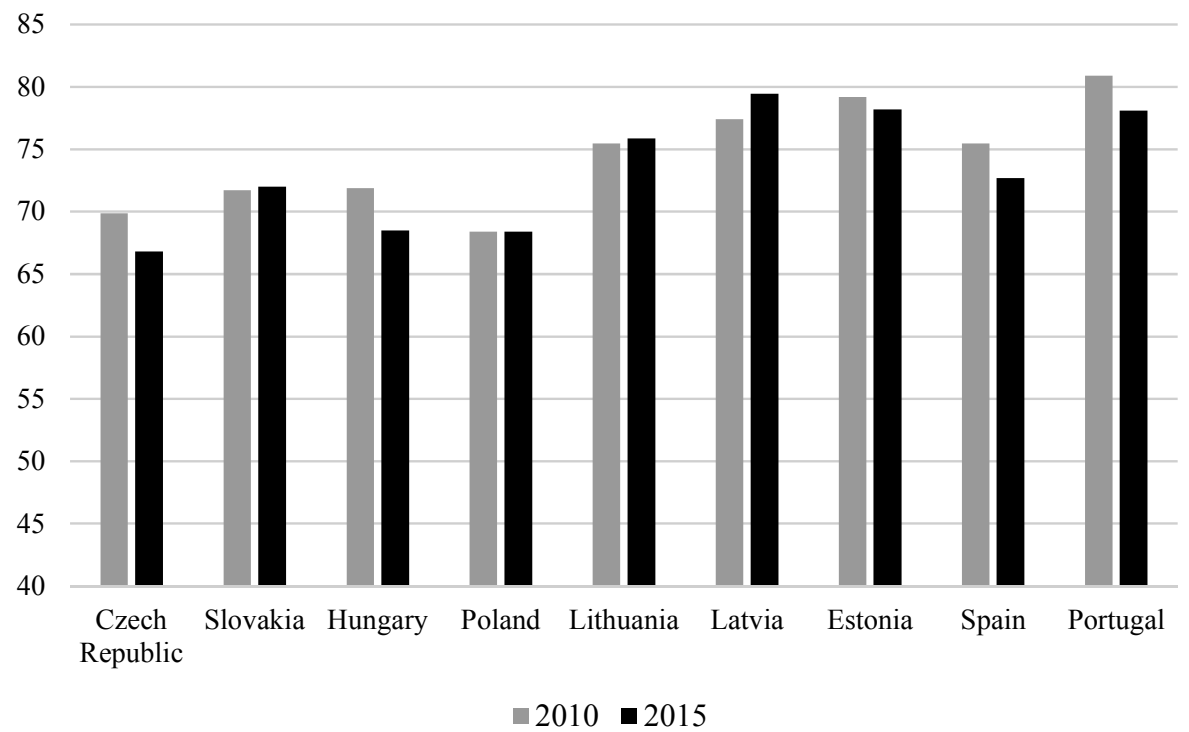

Figure 2. Share of SMEs in the total employment of companies

Source: Eurostat Structural Business Statistics

In the Baltic economies, SMEs play a central role. In Estonia, the number of micro-enterprises and their share in employment increased radically after 1994. SMEs now account for $76 \%$ of value added, nearly 19 percentage points more than the EU average. After the crisis, Latvian SMEs grew strongly, however, both value added and employment remained below their 2008 level in 2015. Mediumsized firms contribute a particularly high share of value added, 26.6\% (see Table 2 ), which is well above the EU average of $18.2 \%$. The average Latvian SME has 4.5 employees due to this, higher than the EU average of 3.9 (European Commission 2017). Regarding Lithuania, in 2010-2015, SME value added increased by more than $50 \%$ and SME employment increased by almost $20 \%$. As a result, SME value added in 2015-2016 was already above its 2008 level, but SME employment has not yet fully recovered. Medium-sized firms contribute $27.7 \%$ of value added, which is also substantially more than the EU average (European Commission 2017).

Table 2 shows that the share of SMEs in value added is the lowest in the Visegrád countries of the three regions. With the contribution of SMEs the Polish economy recovered relatively rapidly from the crisis, producing positive annual growth rates since 2010. In 2015, Czech SMEs returned to 2008 levels of value added, although large firms performed better. Total SME employment appeared 
Table 2. Share of companies according to firm size, 2016, $\%$

\begin{tabular}{|c|c|c|c|c|c|c|}
\hline & & $\begin{array}{c}\text { Micro } \\
0-10\end{array}$ & $\begin{array}{l}\text { Small } \\
11-49\end{array}$ & $\begin{array}{c}\text { Medium } \\
50-249\end{array}$ & Total SME & $\begin{array}{l}\text { Large } \\
250+\end{array}$ \\
\hline \multirow[t]{3}{*}{$\mathrm{PT}$} & Number & 95.1 & 4.2 & 0.6 & 99.9 & 0.1 \\
\hline & Employment & 40.9 & 20.9 & 16.4 & 78.1 & 21.9 \\
\hline & Value added & 24.2 & 22.1 & 22.3 & 68.5 & 31.5 \\
\hline \multirow[t]{3}{*}{ ES } & Number & 94.9 & 4.4 & 0.6 & 99.9 & 0.1 \\
\hline & Employment & 41.2 & 18.3 & 13.1 & 72.6 & 27.4 \\
\hline & Value added & 25.9 & 18.1 & 17.8 & 61.8 & 38.2 \\
\hline \multirow[t]{3}{*}{$\mathrm{EE}$} & Number & 90.5 & 7.7 & 1.5 & 99.8 & 0.2 \\
\hline & Employment & 30.4 & 24.4 & 23.2 & 78.0 & 22.0 \\
\hline & Value added & 26.2 & 23.3 & 26.2 & 75.7 & 24.3 \\
\hline \multirow[t]{3}{*}{$\mathrm{LV}$} & Number & 91.5 & 7 & 1.3 & 99.8 & 0.2 \\
\hline & Employment & 31.8 & 24.5 & 22.7 & 79.0 & 21.0 \\
\hline & Value added & 20.4 & 22.8 & 26.6 & 69.8 & 30.2 \\
\hline \multirow[t]{3}{*}{ LT } & Number & 92.6 & 6.1 & 1.2 & 99.8 & 0.2 \\
\hline & Employment & 29.0 & 24.3 & 22.6 & 75.9 & 24.1 \\
\hline & Value added & 19.0 & 23.3 & 27.7 & 69.9 & 30.1 \\
\hline \multirow[t]{3}{*}{$\mathrm{PL}$} & Number & 95.3 & 3.6 & 0.9 & 99.8 & 0.2 \\
\hline & Employment & 36.8 & 13.9 & 17.8 & 68.4 & 31.6 \\
\hline & Value added & 18.4 & 13.8 & 20.4 & 52.5 & 47.5 \\
\hline \multirow[t]{3}{*}{$\mathrm{CZ}$} & Number & 96.0 & 3.1 & 0.7 & 99.8 & 0.2 \\
\hline & Employment & 31.0 & 17.2 & 18.6 & 66.8 & 33.2 \\
\hline & Value added & 19.6 & 14.4 & 20.5 & 54.5 & 45.5 \\
\hline \multirow[t]{3}{*}{ SK } & Number & 96.8 & 2.6 & 0.5 & 99.9 & 0.1 \\
\hline & Employment & 41.8 & 14.8 & 15.5 & 72.1 & 27.9 \\
\hline & Value added & 22.8 & 14.2 & 17.4 & 54.4 & 45.6 \\
\hline \multirow[t]{3}{*}{$\mathrm{HU}$} & Number & 94.1 & 4.9 & 0.8 & 99.8 & 0.2 \\
\hline & Employment & 33.9 & 18.9 & 15.7 & 68.5 & 33.4 \\
\hline & Value added & 18.0 & 16.7 & 18.2 & 52.9 & 47.1 \\
\hline
\end{tabular}

Source: Compilation from the 2017 SBA Fact Sheets of the countries

to be largely unaffected by the crisis, job losses of small and medium-sized firms were largely absorbed by increasing employment in microenterprises. Slovak SMEs have started to recover since 2014 following a sharp downturn. The role of microenterprises in employment is high, similar to the Iberian case. In Hungary, SMEs almost fully returned to their pre-crisis level of value added in 2015, but SME employment was still 7\% below its 2008 level (European Commission 2017). Hungary's share of small firms in employment is the highest among the Visegrád countries.

The analysis of the three peripheral regions prompts a comparison to core EU countries (Table 3). Germany stands out with its high share of small and me- 
Table 3. Share of companies according to size, 2016, \%, selected core countries

\begin{tabular}{l|l|r|r|r|r|r}
\hline & & $\begin{array}{c}\text { Micro } \\
0-10\end{array}$ & $\begin{array}{c}\text { Small } \\
11-49\end{array}$ & $\begin{array}{c}\text { Medium } \\
50-249\end{array}$ & Total SME & $\begin{array}{c}\text { Large } \\
250+\end{array}$ \\
\hline IT & Number & 95.1 & 4.3 & 0.5 & $\mathbf{9 9 . 9}$ & 0.1 \\
\hline & Employment & 46.0 & 20.1 & 12.5 & $\mathbf{7 8 . 6}$ & 22.4 \\
\hline & Value added & 29.3 & 20.8 & 17.6 & $\mathbf{6 7 . 7}$ & 32.3 \\
\hline \hline FR & Number & 95.7 & 3.6 & 0.6 & $\mathbf{9 9 . 9}$ & 0.1 \\
\hline & Employment & 31.9 & 17.6 & 13.7 & $\mathbf{6 3 . 2}$ & 36.8 \\
\hline & Value added & 23.1 & 16.7 & 14.7 & $\mathbf{5 4 . 5}$ & 45.5 \\
\hline DE & Number & 83.7 & 13.7 & 2.2 & $\mathbf{9 9 . 6}$ & 0.4 \\
\hline & Employment & 20.2 & 23.2 & 20.0 & $\mathbf{6 3 . 4}$ & 36.6 \\
\hline & Value added & 16.3 & 18.1 & 19.7 & $\mathbf{5 4 . 1}$ & 45.9 \\
\hline AT & Number & 87.3 & 10.7 & 1.6 & $\mathbf{9 9 . 7}$ & 0.3 \\
\hline & Employment & 25.6 & 24.1 & 19.1 & $\mathbf{6 8 . 7}$ & 31.3 \\
\hline & Value added & 18.7 & 20.6 & 22.6 & $\mathbf{6 2 . 0}$ & 38.0 \\
\hline
\end{tabular}

Source: 2017 SBA Fact Sheets

dium sized firms, but regarding value-added its company structure is similar to Hungary, the Czech Republic and Poland. The high share of Austrian small and medium sized firms in value added is similar to the pattern of the Baltic countries. The French company structure with its very high role of micro-firms in employment is similar to the Iberian situation. The role of SMEs in the economies of the three regions is not radically different from the EU-core.

\subsection{Export of SMEs}

According to the EIM (2010) survey, generally 25\% of EU SMEs had direct export activities in 2006-2008. This proportion essentially remained unchanged after the crisis. The majority of our nine countries match this average figure, but there are two extremes: in Hungary only around $18 \%$ of SMEs exported and in Estonia more than $50 \%$ did. ${ }^{13}$ Data refer to direct exports, but indirect exports (with the inclusion of an intermediary) can also have some significance in these countries..$^{14}$

13 Figures for the Czech Republic and Portugal are also above $30 \%$.

14 For Estonian companies there was a huge increase in indirect exports (from $6 \%$ to $20 \%$; Eurofound (E) 2013) between 2008 and 2011. The main reason is that Estonian new SMEs generally lacked export-related knowledge and skills; only half of the exporters fulfilled ad hoc export orders and only every sixth company had an export strategy and export budget. 
Table 4. Distribution of exporting firms by size, number and value in 2008 and 2015, \%

\begin{tabular}{|c|c|c|c|c|c|c|c|c|c|c|c|c|}
\hline \multirow[t]{3}{*}{ Employees } & \multicolumn{3}{|c|}{$0-9$} & \multicolumn{3}{|c|}{$10-49$} & \multicolumn{3}{|c|}{$50-250$} & \multicolumn{3}{|c|}{250 or more } \\
\hline & \multirow{2}{*}{$\begin{array}{c}\text { No. } \\
2015\end{array}$} & \multicolumn{2}{|c|}{ Value } & \multirow{2}{*}{$\begin{array}{c}\text { No. } \\
2015\end{array}$} & \multicolumn{2}{|c|}{ Value } & \multirow{2}{*}{$\begin{array}{c}\text { No. } \\
2015\end{array}$} & \multicolumn{2}{|c|}{ Value } & \multirow{2}{*}{$\begin{array}{c}\text { No. } \\
2015\end{array}$} & \multicolumn{2}{|c|}{ Value } \\
\hline & & 2008 & 2015 & & 2008 & 2015 & & 2008 & 2015 & & 2008 & 2015 \\
\hline Spain & 69.9 & 10.3 & 10.9 & 20.0 & 14.0 & 13.1 & 5.4 & 23.4 & 21.6 & 1.5 & 52.3 & 45.6 \\
\hline Portugal & 63.7 & 7.7 & 9.2 & 23.7 & 12.7 & 16.2 & 5.9 & 26.1 & 25.7 & 1.1 & 45.4 & 40.8 \\
\hline Estonia & 62.9 & 13.5 & 18.0 & 15.8 & 21.7 & 16.9 & 4.8 & 37.3 & 33.6 & 0.9 & 15.9 & 27.5 \\
\hline Latvia & 65.8 & 11.0 & 16.5 & 24.9 & 23.4 & 21.6 & 6.9 & 36.1 & 34.5 & 1.3 & 27.7 & 17.5 \\
\hline Lithuania & 60.7 & 6.5 & 11.3 & 29.0 & 13.2 & 13.3 & 8.5 & 25.2 & 22.2 & 1.7 & 32.7 & 32.2 \\
\hline Poland & 69.0 & 5.4 & 5.1 & 20.7 & 7.8 & 7.5 & 7.3 & 19.7 & 15.4 & 2.1 & 67.0 & 53.2 \\
\hline Czech R & 28.2 & 4.5 & 3.3 & 25.4 & 8.1 & 6.1 & 16.2 & 19.6 & 13.6 & 5.3 & 63.1 & $43.7^{*}$ \\
\hline Slovakia & 57.5 & 7.1 & 7.1 & 17.3 & 16.6 & 5.5 & 5.7 & 11.5 & 11.8 & 1.4 & 62.4 & 62.6 \\
\hline Hungary & 68.9 & 5.5 & 26.2 & 22.4 & 5.7 & 5.5 & 6.8 & 14.4 & 14.4 & 1.8 & 66.1 & 52.2 \\
\hline
\end{tabular}

Note: There is usually an "unknown" group in the database; therefore, the cells in rows do not necessarily add up to $100 \%$.

*The share of "unknown" group is extremely large (33\%) in Czech data.

Source: Calculations based on Eurostat, Trade by Enterprise Characteristics.

There is considerable difference among the three regions concerning the value of exports by SMEs. Table 4 shows that SMEs had by far the largest role in the Baltic economies in 2008, meanwhile in the Visegrád countries over $60 \%$ of exports was provided by large companies (who represent only 1-5 percent of total number of enterprises). Iberian economies were "in between", with large enterprises playing a smaller role in exports.

2015 brought large changes. In Estonia, the export share of large companies increased significantly, but stagnated in Lithuania and decreased in Latvia. The important role of large companies remained in the Visegrád countries, although it slightly declined in Hungary, while exports of micro-enterprises increased. ${ }^{15}$ Little change occurred in the Iberian countries.

For exporting European SMEs geographically close markets are the most important, meaning the EU. A thin stream of literature speaks directly about "Europeanisation" of the firm as sub-category of internationalization or globalisation (Harris - McDonald 2004; Wach 2016a). On average, internationalised European SMEs achieved almost $90 \%$ of their total turnover from the single European market (Wach 2014).

The question is whether the crisis reinforced this Europeanisation or just the opposite. The foreign trade data of the firms show a kind of geographic rearrangement between 2008-2013, (increased exports to non-EU countries and a slower increase to EU countries) for the nine countries (see Table 5). Spanish and Por-

15 Part of this export exists only on paper, see Reuters (2012). 
Table 5. Export value increase/decrease of SMEs according to size and area between 2008-2013 and 2013-2015

\begin{tabular}{l|l|c|c|c|c|l|c|c|c|c}
\hline & $2013 / 08$ & Micro & Small & Medium & Large & $2015 / 13$ & Micro & Small & Medium & Large \\
\hline PT & Extra-EU & 1.69 & 1.76 & 1.71 & 1.14 & Extra-EU & 0.80 & 0.98 & 1.01 & 0.91 \\
\hline & EU & 1.62 & 1.45 & 1.05 & 1.11 & EU & 1.00 & 1.09 & 1.10 & 1.08 \\
\hline ES & Extra-EU & 1.28 & 1.49 & 1.31 & 1.58 & Extra-EU & na & na & na & na \\
\hline & EU & 1.20 & 1.15 & 1.12 & 1.03 & EU & na & na & na & na \\
\hline EST & Extra-EU & 2.70 & 1.18 & 1.08 & 2.03 & Extra-EU & na & na & na & na \\
\hline & EU & 2.35 & 1.12 & 1.44 & 2.68 & EU & na & na & na & na \\
\hline LIT & Extra-EU & 1.88 & 1.38 & 1.16 & 1.28 & Extra-EU & 0.71 & 0.71 & 0.86 & 0.80 \\
\hline & EU & 2.91 & 1.50 & 1.38 & 1.21 & EU & 1.30 & 1.20 & 1.04 & 0.83 \\
\hline LV & Extra-EU & 1.59 & 1.60 & 2.22 & 1.23 & Extra-EU & 1.41 & 0.98 & 0.90 & 0.78 \\
\hline & EU & 3.33 & 1.39 & 1.61 & 0.99 & EU & 0.85 & 1.19 & 0.98 & 1.22 \\
\hline PL & Extra-EU & 1.54 & 1.63 & 1.31 & 1.48 & Extra-EU & 0.81 & 0.87 & 0.95 & 0.94 \\
\hline & EU & 1.23 & 1.55 & 1.27 & 1.16 & EU & 1.34 & 1.10 & 1.08 & 1.18 \\
\hline CZ & Extra-EU & 1.61 & 1.16 & 1.43 & 1.44 & Extra-EU & 0.73 & 0.90 & 0.97 & 0.99 \\
\hline & EU & 1.13 & 1.22 & 1.13 & 0.97 & EU & 1.20 & 1.13 & 1.05 & 1.20 \\
\hline SK & Extra-EU & 1.39 & 0.51 & 3.51 & 1.40 & Extra-EU & 1.01 & 0.90 & 0.43 & 1.00 \\
\hline & EU & 1.67 & 0.49 & 3.08 & 1.09 & EU & 0.92 & 1.02 & 0.50 & 1.42 \\
\hline HU & Extra-EU & 4.83 & 0.97 & 1.10 & 0.99 & Extra-EU & 0.84 & 0.98 & 1.03 & 0.89 \\
\hline & EU & 5.32 & 1.15 & 1.19 & 0.95 & EU & 1.25 & 1.05 & 1.06 & 1.16 \\
\hline
\end{tabular}

Source: author's calculation based on Eurostat Trade by Enterprise Characteristics data

tuguese, Polish and Czech SMEs of all sizes and large companies increased their exports to non-EU markets more than to the EU. In the other countries, there are certain exceptions from this trend: Estonian medium and large firms, Lithuanian SMEs, and Latvian, Hungarian, Slovakian micro enterprises. As for these latter, micro enterprises exported only some $5-10 \%$ of the total export values of the given countries, we can state that the bulk of firms' export increased more to nonEU countries. This geographical "rearrangement", however, proved to be temporary, because after 2013, the weight of the EU increased again in exports. Trade data of SMEs where available show that extra-EU exports actually decreased or stagnated, while deliveries to EU markets increased in 2013-15. It seems that the EU remains the most important market, with even reinforced weight.

\section{CONCLUSIONS}

SMEs in the Baltic, Visegrád and Iberian countries have already overcome the negative effects of the international crisis of 2008. Recovery was the most difficult and took the longest in Spain and Portugal, where low domestic demand was a push factor for internationalization. Exports remained the main form of inter- 
nationalization of SMEs in all three regions. Companies show a variety of internationalization methods providing examples to theories that are briefly presented in this article. One especially relevant approach is the network theory, because SMEs in the Visegrád and Iberian countries are strongly integrated into global production chains. Another relevant model is international new ventures, because we can find several "born globals" in all the three regions. Baltic and Visegrád countries are not different from general patterns, since born global firms appeared in the 1990s, during the transition to a market economy.

Motivation and stimuli for the internationalization of SMEs in the three regions are based on company surveys that focus on the post-crisis period. External factors included domestic market shrinkage in the Iberian countries and opportunities in foreign markets for the CEE countries. However, the importance of internal factors proved to be much larger. Two stimuli were especially important in every country: the role of management (proactive behaviour, expertise, vision) and innovation. This mimics other global and EU economies.

Regarding the number of firms, the share of SMEs is over $99 \%$ in each country, but the significance of SMEs in employment, value added and exports differs in the three regions. Compared to the other two regions, SMEs represent less weight in the Visegrád countries, but their pace of recovery from the crisis was the quickest. The share of micro enterprises is the largest in the employment of the Iberian countries. The weight of small and medium-sized firms in value added is the largest in the Baltic countries. These differences are not irregular; SME shares vary in the core EU countries too, making them similar to one or another peripheral country.

There is a considerable difference among the three regions concerning the value of exports by SMEs. SMEs had by far the largest role in the Baltic economies in 2015, meanwhile in the Visegrád countries large companies provided over 50\% of exports. Iberian economies are between the two, with a $40-45 \%$ share.

As given in the theory of internationalization, psychic distance is important. Peripheral SMEs (first of all micro and small enterprises) mostly export to the neighbouring and culturally close countries. These countries are EU members; therefore, the EU's role is key as an export destination. Although between 2010 and 2013 the export of SMEs to non-EU areas increased more rapidly than within the EU, the phenomenon proved to be temporary. The EU remains the most important market for peripheral SMEs, which do not significantly differ from other member states' SMEs in terms of their structural role in the economy or their motivations to internationalise. 


\section{REFERENCES}

Antalóczy, K. - Éltető, A. (2016): Post-Crisis Foreign Trade Trends and Policies on the Periphery of the European Union - Comparison of the Iberian, Baltic and Central European Region. IWE Working Papers no. 224.

Banco de España (2015): La internacionalización de las Pymes españolas: principales desarrollos recientes y sus determinantes. Boletín Económico, Diciembre.

Banco de Portugal (2017): Análise das empresas do setor exportador em Portugal - 2007-2016. Nota de Informaçao Estatistica 122.

Bell, J. - McNaugthon, R. - Young, S. (2001): Born-Again Global' Firms: An Extension to the 'Born Global' Phenomenon. Journal of International Management 7(3): 173-189.

Bonet-Ferrer, J. R - Mínguez Fuentes, R. (2015): Crecimiento de la dimensión de la PYME española por la vía de la internacionalización. Revista ICE 885: 93-115.

Caputo, A. - Pellegrini, M. - Dabic, M. - Dana, L. P (2016): Internationalization of Firms from Central and Eastern Europe: A Systematic Literature Review. European Business Review 28 (6): 630-651.

Carlos Lopes, J. - Branco, A. - Parejo, F. - Francisco Rangel, J. (2014): Determinants of Success and Failure in the Internationalization of the Cork Business: A Tale of Two Iberian Family Firms. In: Bilgin M. - Danis H. (eds) Entrepreneurship, Business and Economics Vol. 2. Eurasian Studies in Business and Economics 3(2). Springer, pp. 417-404.

Cavusgil, S. T. (1980): On the Internationalization Process of Firms. European Research 8(6): 273-281.

CEDI (2015): Estudio Internacionalización Empresas Españolas. Spanish Committee for Company Internationalization. Madrid: MillwardBrown. https:/www.camara.es/sites/default/files/ publicaciones/estudio.pdf, accessed 25/09/2018.

Correia, A. L - Gouveia, A. F. (2016): What Determines Firm-level Export Capacity? Evidence from Portuguese firms. GEE Papers 57.

Coviello, N. E. - Munro, H. J. (1997): Network Relationships and the Internationalization Process of Smaller Software Firms. International Business Review 6(4): 361-384.

Czerniak, A. - Stefanski, M. (2015): Small and Medium Enterprises in Poland - Obstacles and Development. Polityka Insight Research 186.

Danik, L. - Duliniec, E. - Kowalik, I. (2016): The Polish Born Global Firms: Founding Processes and Motives of Early Internationalization. Transformation in Business \& Economics 15(2): $111-130$.

Danik, L. - Kowalik, I. - Král, P. (2016): A Comparative Analysis of Polish and Czech International New Ventures. Central European Business Review 5(2): 57-72.

Danik, L. - Kowalik, I. (2015): Success Factors and Development Barriers Perceived by the Polish Born Global Companies. Empirical Study Results. Journal of East European Management Studies 20(3): 360-390.

Deloitte - AICEP (2014): Estudo sem fronteiras: PMEs levantam voo. Lisbon: Deloitte.

Deloitte (2016): Versenyképességi Indikátor jelentés - feltörekvő középvállalatok [Indicators of Competitiveness - Emerging Medium Sized Firms]. Budapest: Deloitte.

Dominguez, N. - Mayrhofer, U. (2017): Internationalization Stages of Traditional SMEs: Increasing, Decreasing and Re-Increasing Commitment to Foreign Markets. International Business Review 26(6): 1051-1063.

Doole, I. - Grimes, T. - Demack, S. (2006): An Exploration of the Management Practices and Process Most Closely Associated with Levels of Export Capability in SMEs. Marketing Intelligence \& Planning 24 (6): 632-647. 
Ecorys (2011): Are EU SMEs Recovering from the Crisis? Annual Report on EU Small and Medium sized Enterprises 2010/2011. Rotterdam: Ecorys.

EIM (2010): Internationalization of European SMEs. Final Report, Zoetermer - Brussels: European Commission - EIM Business \& Policy Research.

Estonian Ministry of Economic Affairs (2015): Eesti eksportööride konkurentsivõime uuring [Estonian Exporters Competitiveness Study. Final Report]. Talinn: Estonian Ministry of Economic Affairs

Etemad, H. (2004): Internationalization of Small and Medium Enterprises: a Grounded Theoretical Framework and an Overview, Canadian Journal of Administrative Sciences 1(1): 1-21.

Eurofound (E) (2013): Restructuring in SMEs: Estonia. Dublin: Eurofond.

Eurofound (L) (2013): Restructuring in SMEs: Latvia. Dublin: Eurofond.

Eurofound (H) (2013): Restructuring in SMEs: Hungary. Dublin: Eurofond.

European Commission (2017): SBA Fact Sheets on Estonia, Latvia, Lithuania, Spain, Portugal, Hungary, Slovakia, Poland, Czech Republic. https://ec.europa.eu/growth/smes/business-friendlyenvironment/performance-review_en\#sba-fact-sheets, accessed 25/09/2018.

Fernández-Olmos, M. - Gargallo-Castel, A. - Giner-Bagües, E. (2016): Internationalization and Performance in Spanish Family SMES: The W-Curve. Business Research Quarterly 19(2): 122-136.

Fernandez-Serrano, J. - Romero, I (2013): Entrepreneurial Quality and Regional Development: Characterizing SME Sectors in Low Income Areas. Papers in Regional Science 92(3): 495514.

Fonfara, K. (2011): A Typology of Company Behaviour in the Internationalization Process (a Network Approach). The Poznań University of Economics Review 11(2): 5-25.

Gankema, H. G. J. - Snuif, H. R. - Zwart, P. S. (2000): The Internationalization Process of Small and Medium Sized Enterprises: An Evaluation of Stage Theory. Journal of Small Business Management 38 (4): 15-27.

García-Canal, E. (2013): The International Expansion of Spanish Firms: Strengths and Weaknesses. SEFO Spanish Economic and Financial Outlook 2(6): 63-74.

Garrido Prada, P. - Delgado Rodríguez, M. J - Romero Jordán, D. (2016): Spanish Listed Firms in the Last Period of Economic Crisis: The Performance of Corporate Diversification. FUNCAS Documento de Trabajo 783/2016

Gelbuda, M. - Meyer, K. E - Delios, A. (2008): International Business and Institutional Development in Central and Eastern Europe. Journal of International Management 14: 1-11.

González, J. - Martín, C. (2015): La Internacionalización de Las Pymes Espanolas: Principales Desarrollos Recientes y Sus Determinantes. Banco de Espana Boletín Económico 12: 43-54.

Harris, P. - McDonald, F. (2004): European Business \& Marketing, 2nd ed., London - Thousand Oaks- New Delhi: SAGE Publications.

Horská, E. - Gálová, J. (2014): Patterns of Business Internationalization in Slovakia: Empirical Results from the V4 Survey. In: Durendez, A. - Wach, K. (eds): Patterns of Business Internationalization in Visegrad Countries - In Search for Regional Specifics. Cartagena: Universidad Politécnica de Cartagena, pp. 103-124.

Hutchinson, K. - Alexander, N. - Quinn, B. (2005): The Internationalization of Small to Medium-Sized Retail Firms: Towards a Conceptual Framework. Journal of Marketing Management 21(1-2): 149-179.

Inzelt, A. (2017): The Internationalization of Hungarian Small and Medium-Sized Enterprises. Eastern European Business and Economics Journal 3(4): 376-396.

Jankowska, B. - Glówka, C. (2016): Clusters on the Road to Internationalization - Evidence from a CEE Economy. Competitiveness Review 26(4): 395-414. 
Jarosiński, M. (2013): Contemporary Models of Polish Firms' Internationalization - Literature and Research Review. Journal of Economics and Management 13: 58-65.

Javalgi, R. G. - Deligounul, S. - Dixit, A. - Cavusgil, S. T. (2011): International Market Reentry: A Review and Research Framework, International Business Review 20(4): 377-393.

Johanson, J. - Mattson, L. G. (1988): Internationalization in Industrial Systems - A Network Approach. In: Hood, N. - Vahlne, J. E. (eds): Strategies in Global Competition. New York: Croom Helm, pp. 287-314.

Johanson, J. - Vahlne, J.-E. (1977): The Internationalization Process of the Firm - A Model of Knowledge Development and Increasing Foreign Market Commitment. Journal of International Business Studies 8(1): 23-32.

Johanson, J. - Vahlne, J.-E. (1990): The Mechanisms of Internationalization. International Marketing Review 7(4): 11-24.

Johanson, J. - Wiedersheim-Paul, F. (1975): The Internationalization of the Firm: Four Swedish Cases. Journal of Management Studies 12(3): 305-322.

Kalinic, I. - Forza, C. (2012): Rapid Internationalization of Traditional SMEs: Between Gradualist Models and Born Globals. International Business Review 21(4): 694-707.

Kazai Ónodi, A. - Pecze, K. (2014): Behind the Exporters' Success: Analysis of Successful Hungarian Exporter Companies from a Strategic Perspective. Managing Global Transitions 12(4): 325-346.

Kokavcová, D. (2016): Rapid Internationalization - Applying the Born Global Company Model in Slovak Companies. Proceedings of 16th International Joint Conference Central and Eastern Europe in the Changing Business Environment, 27 May. Prague: University of Economics and Bratislava: University of Economics in Bratislava, pp. 227-237.

Korsakienè, R. - Tvaronavičienè, M. (2012): The Internationalization of SMEs: An Integrative Approach. Journal of Business Economics and Management 13(2): 294-307.

Korsakienè, R. (2014): Internationalization of Lithuanian SMEs: Investigation of Barriers and Motives. Economics and Business 26: 54-60.

Kovács, G. D. (2014): Internationalization Strategy of Born Global Firms. Thesis, School of Business and Social Sciences, Aarhus University.

Kowalik, I. - Danik, L. - Král, P. - Rezanková, H. (2016): Antecedents of Accelerated Internationalization of Polish and Czech Small and Medium-Sized Enterprises. Entrepreneurial Business and Economics Review 5(3): 31-48.

Kubícková, L. - Votoupalová, M. - Toulová, M. (2014): Key Motives for Internationalization Process of Small and Medium-Sized Enterprises. Procedia Economics and Finance 12: 319328.

Laghzaoui, S. (2011): SMEs' Internationalization: An Analysis with the Concept of Resources and Competences. Journal of Innovation Economics \& Management 1(7): 181-196.

Lejárraga, I. - Lopez, H. R. - Oberhofer, H. - Stone, S. - Sepherd, B. (2014): Small and MediumSized Enterprises in Global Markets: A Differential Approach for Services? OECD Trade Policy Papers 165.

Leonidou, L. (2004): An Analysis of the Barriers Hindering Small Business Export Development. Journal of Small Business Management 43(3): 279-302.

Leonidou, L. C. - Katsikeas, C. S. (1996): The Export Development Process: An Integrative Review of Empirical Models. Journal of International Business Studies 27(3): 517-551.

Leonidou, L. C. - Katsikeas, C. S. - Coudounaris, D. N. (2010): Five Decades of Business Research into Exporting: A Bibliographic Analysis. Journal of International Management 16(1): 78-91.

Lin, S. (2010): Internationalization of the SME: Towards an Integrative Approach of Resources and Competences. 1er Colloque Franco-Tcheque: Trends in International Business, pp.117-135. 
Lu, J. - Beamish, P. W. (2001): Network Development and Firm Performance: A Field Study of Internationalizing Japanese Firms. The Multinational Business Review 12(3): 41-61.

Macedo, M. F. A. T. (2010): Estratégias de internacionalização das empresas da Região Norte de Portugal. Dissertation, Faculty of Economics, University of Porto.

Malecka, J. (2017): The Role of SMEs in International Trade: Selected Aspects. Institute of Economic Research Working Papers 68.

Malega, P. (2017): Small and Medium Enterprises in the Slovak Republic - Competitiveness of Slovak SME's in the Global Markets. In: Vemić, M. (ed.): Optimal Management Strategies in Small and Medium Enterprises. Higher School of Academic Studies "DOSITEJ”, pp. 102-124.

Merino, F. - Monreal, P. - Sánchez-Martin, G. (2015): Family SMEs' Internationalization: Disentangling the Influence of Familiness on Spanish Firms' Export Activity Journal of Small Business Management 53(4): 1164-1184.

Mets, T. (2016): Is Estonia Becoming Better Home for "Born Globals"? In: Smallbone, D. Virtanen, M. - Sauka, A. (eds): Entrepreneurship, Innovation and Regional Development. Cheltenham: Edward Elgar, pp. 101-124.

Musteen, M. - Datta, D. - Francis, J. (2014): Early Internationalization by Firms in Transition Economies into Developed Markets: The Role of International Networks. Global Strategy Journal 4: 221-237.

OECD (2009): The Impact of the Global Crisis on SME and Entrepreneurship Financing and Policy Responses. Paris: OECD.

Ojala, A. (2015): Geographic, Cultural, and Psychic Distance to Foreign Markets in the Context of Small and New Ventures. International Business Review 24(5): 825-835.

Oliveira, P. - Teixeira, A. (2011): The Internationalization Profiles of Portuguese SMEs. FEP Working Papers no. 439.

Ortiz, R. F - Ortiz, J. A. - Clavel San Emeterio, M. (2015): Factors That Foster Export Commitment: An Empirical Study in Small and Medium-Sized Enterprises. Engineering Economics 26(3): $272-283$.

Oviatt, B. M. - McDougall, P. P. (1994): Toward a Theory of International New Ventures. Journal of International Business Studies 25(1): 45-64.

Pinilla Jara, J. (2016): Innovación e internacionalización exportadora en las PYMES industriales catalanas. El papel de las orientaciónes estratégicas. Doctoral Thesis, Autonomous University of Barcelona, Faculty of Economics and Business.

Putniņšs, T. (2013): Exporting by Latvian Companies: Vitality, Drivers of Success, and Challenges. Baltic Journal of Economics 13(2): 3-33.

Rasmussen, E. - Madsen, T. K. (2002): The Born Global Concept. Paper presented at the $28^{\text {th }}$ EIBA Conference.

Reid, S. D. (1981): The Decision-Maker and Export Entry and Expansion. Journal of International Business Studies 12(2): 101-112.

Reková, E. (2016): The "Born Globals" Phenomenon in Czech Republic. Paper presented at the $9^{\text {th }}$ International Scientific Conference "Business and Management 2016", 12-13 May, 2016, Vilnius, Lithuania.

Rennie, M. W. (1993): Born Global. The McKinsey Quarterly 4: 43-52.

Reuters (2012): Exclusive: Hungary Losing 1 Billion Euros a Year from Food VAT Fraud. http:// www.reuters.com/article/us-hungary-vat-fraud/exclusive-hungary-losing-1-billion-euros-ayear-from-food-vat-fraud-idUSBRE85614B20120607, accessed 25/09/2018.

Ribau, C. - Carriso Moreira, A. - Raposo, M. (2018): SME Internationalization Research: Mapping the State of the Art. Canadian Journal of Administrative Sciences 35(2): 280-303. 
Rod, M. - El Banna, M. - Munim, A. (2016): SME Internationalization: A Critical Review of NonTraditional Approaches. Paper presented at the $32^{\text {nd }}$ IMP Conference in Poznan, Poland.

Ruzzier, M. R. - Hisrich, D. - Antoncic, B. (2006): SME Internationalization Research: Past, Present and Future. Journal of Small Business Enterprise Development 13(4): 476-497.

Sánchez, P. - Gallego, E. - Rivero, D. - Lagos Peñas, S. (2014): The Impact of Internationalization on Firms: Empirical Evidence for the Spanish Case. MPRA Paper 5462.

Sarasvathy, S. (2001): Causation and Effectuation: Toward a Theoretical Shift from Economic Inevitability to Entrepreneurial Contingency. The Academy of Management Review 26(2): 243263.

Sekliuckiene, J. (2014): The Role of Networks in Internationalization of Born Global Information Technology Firms: The Case of SMEs in Lithuania. In: Vrontis, D. - Weber, Y. - Tsoukatos, E. (eds): $7^{\text {th }}$ Annual EuroMed Conference of the EuroMed Academy of Business - The Future of Entrepreneurship. EuroMed Research Business Institute, pp. 1463-1475.

Sekliuckiene, J. (2017): Factors Leading to Early Internationalization in Emerging Central and Eastern European Economies: Empirical Evidence from New Ventures in Lithuania. European Business Review 29(2): 1-31.

Stoian, M. C. - Rialp, A. - Rialp, J. - Jarvis, R. (2016): Internationalization of Central and Eastern European Small Firms. Journal of Small Business and Enterprise Development 23(1): 105121.

Szerb, L. - Márkus, G. - Csapi, V. (2013): Kifizetődő-e a magyar vállalatok számára a nemzetköziesedés? [Is It Worth Internationalising for the Hungarian Companies?] http://www. mkt.hu/vandorgyules/2013/Szerb_Laszlo.pdf, accessed 25/09/2018.

Toulová, M. - Votoupalová, M. - Kubícková, L. (2015): Barriers of SMEs Internationalization and Strategy for Success in Foreign Markets. International Journal of Management Cases 17: 4-19.

Vissak, T. (2010): Nonlinear Internationalization: A Neglected Topic in International Business Research. In: Devinney, T. - Pedersen, T. - Tihanyi, L. (eds): The Past, Present and Future of International Business \& Management. Emerald Group Publishing Limited, pp. 559-580.

Vissak, T. - Francioni, B. (2013): Serial Nonlinear Internationalization in Practice: A Case Study. International Business Review (22): 951-962.

Wach, K. (2014): The Scale of Internationalization and Europeanisation of SMEs and Their Functioning in the Spatial Systems of the European Union. Przedsiębiorczość - Edukacja 10: 136148.

Wach, K. (2016a): Europeanisation of European Businesses: Economies of Scope and Managerial Implications. Horyzonty Polityki 7(19): 151-172.

Wach, K. (2016b): Innovative Behaviour of High-Tech Internationalized Firms: Survey Results from Poland. Entrepreneurial Business and Economics Review 4(3): 153-165.

Welch, C. L. - Welch, L. S. (2009): Re-Internationalization: Exploration and Conceptualization. International Business Review 18(6): 567-577.

Welch, L. S. - Luostarinen, R. (1988): Internationalization: Evolution of a Concept. Journal of General Management 14(2): 34-55.

Zapletalová, S. (2015): Models of Czech Companies' Internationalization. Journal of International Entrepreneurship 13(2): 153-168.

Zapletalová, S. (2017): International Management of Czech Family Enterprises: Decisions on International Entrepreneurial Activities. Central European Business Review 6(3): 51-61.

Zhang, J. (2014): The Psychic Distance of the Enterprise Internationalization. Wuhan International Conference on e-Business Proceedings, https://aisel.aisnet.org/cgi/viewcontent.cgi?article=106 $8 \&$ context $=$ whiceb2014, accessed 25/09/2018. 